\title{
Revegetation of a salt water blowout site
}

\author{
GARY A. HALVORSON AND KENT J. LANG
}

\begin{abstract}
A salt water blowout at an oil drilling site in 1982 in a badlands area of westem North Dakota caused severe damage to the native vegetation. A study was initiated to measure the effect of reclamation on soils and revegetation of the affected area. Basal cover and plant denaity were measured on a portion of the contaminated area following the blowout and in 1984 following reclamation of the site. The contaminated soll was reclalmed by adding $\mathrm{CaCl}_{6}$ to irrigation water which was used to leach the upper $15 \mathrm{~cm}$ of the soil profile. In July 1982, after the blowout, Distichlis stricta was essentially the only species growing at the site. In July 1984, following reclamation, species with the highest percent basal cover on the reclaimed half were $A$ gropyron smithit (Rydb.), Boutelowa gracilts (H.E.K. Lag.), and Distichlis stricta (Torr.) Rydb. On the unreclaimed half Agropyron smithil, Distichlis stricta, Lepidium denisflorum Schrad., and Opuntia polycantha Haw. had the highest percent basal cover. In 1984, basal cover of the grasses on the reclaimed site was two-thirds of that on a site with no visible damage from the salt water. The percent bare ground was still $25 \%$ on the reclaimed half of the contaminated site in 1984, but had increased on the unreclaimed half to $43 \%$ leaving the surface open to potentially serious erosion. Soll data indicated that reclamation had successfully reduced sodium adsorption ratio (SAR) values in the surface $15 \mathrm{~cm}$ to more acceptable levels for vegetation recovery.
\end{abstract}

Key Words: reclamation, oil well, grasses, forbs, cover

A blowout of an oil well being drilled in western North Dakota occurred on 6 April 1982. Water containing concentrated sodium chloride under pressure from nitrogen gas was forced into the air. The concentrated brine flowed at a rate of more than $3,8001 / \mathrm{min}$. until 14 April, when the flow was shut off. The surrounding area, about 30 ha in size, was contaminated by the brine. The native vegetation within this area was almost completely killed by the brine.

Salt-affected soil can reduce the growth of vegetation by decreasing the ability of the roots to take up water or by specific sodium (Na) toxicity to some species. A high percentage of exchangeable Na may also adversely affect soil structure. Plant species differ in their tolerance to salts. Among the grasses with high salt tolerance are inland saltgrass (Distichlis stricta) ${ }^{\mathfrak{l}}$ and western wheatgrass (Agropyron smithii) (Bernstein 1958). Blue grama (Bouteloua gracilis) is considered moderately tolerant to salt.

Percent germination of forage grasses has been shown to depend on total salt concentration (Miller and Chapman 1978, Ryan et al. 1975) and the type of salt (Ries and Hofmann 1983). Aerial deposition of chloride salts has also been shown to cause injury to growing plants at rates of deposition of $1.1 \mathrm{~kg}$ of salt per ha or less (Francis and Curtis 1979, Petolino and Leone 1980).

A common practice used to reclaim sodium-affected soils is to add a source of calcium to the soil (US Salinity Laboratory staff 1954). Supplemental water is then added to displace the scdium

\footnotetext{
Authors are associate soil scientist and former research assistant, Land Reclamation Research Center, P.O. Box 459, Mandan, North Dakota 58554.

A special thanks is extended to Ron Ries for helpful suggestions and to Gordon Jensen for his help in the plant identification. This research would not have been possible without a grant from Gulf Oil Company (now Chevron USA, Inc.).

Manuscript accepted 8 August 1988.

${ }^{1}$ Authority for species can be found in Tables 1 and 2.
}

and leach it downward through the profile. Calcium chloride $\left(\mathrm{CaCl}_{2}\right)$ is a highly soluble form of calcium that can readily be added to the water in a sprinkler irrigation system. A major disadvantage of $\mathrm{CaCl}_{2}$ is its high cost (Doering and Willis 1975). Calcium chloride is readily available in areas of oil exploration since it is commonly used in drilling muds.

Contamination of land from salt spills is fairly common in areas of oil development, although a salt water blowout is fairly unusual. The occurrence of a salt water blowout provided an opportunity to study vegetation recovery following extreme sodium chloride contamination. The objectives of this study were to: (1) measure the effectiveness of the applied reclamation practices by comparing the kind and quantity of each plant species found at the site on reclaimed and unreclaimed areas: (2) study the changes in sodium adsorption ratio (SAR) and electrical conductivity $\left(\mathbf{E C}_{0}\right)$ as a measure of reclamation effectiveness.

\section{Methods and Materials}

The site was located on the boundary between Dunn County and McKenzie County, North Dakota, in an area of badlands topography consisting of slide slopes, cliffs, buttes, fans, slump blocks, and terraces which originated from Tertiary Period deposits of soft shale, soft sandstone, volcanic ash, and lignite. The average annual precipitation is about $43 \mathrm{~cm}$. Vegetation was relatively diverse with an abundance of Rocky Mountain juniper (Juniperus scopulorum) and a large variety of grasses, forbs, and shrubs on and around more developed soils. Most common grasses were western wheatgrass, sedges (Carex spp.), blue grama, side oats grama (B. curtipendula), inland saltgrass, green needlegrass (Stipa viridula), and needle and thread ( $S$. comata). Common shrubs included sagebrush (Artemisia spp) and buckbrush (Symphoricarpos occidentalis).

Reclamation of this site was conducted by a consulting firm specializing in the reclamation of brine spills. Soil contaminated by the blowout was reclaimed using calcium chloride $\left(\mathrm{CaCl}_{2}\right)$. Calcium chloride was added in irrigation water at the rate of $1,200 \mathrm{~kg}$ $\mathrm{CaCl}_{2} /$ ha to replace the sodium in the surface $15 \mathrm{~cm}$ of the study site. Following the application of $\mathrm{CaCl}_{2}$, the contaminated area was sprinkler irrigated with sufficient water to leach the $\mathrm{Na}$ at least $15 \mathrm{~cm}$ below the surface. Soil samples taken periodically from the site by the reclamation consulting firm were used to determine if additional leaching was necessary.

An area approximately 1 ha in size on a south-facing slope directly west of the well was chosen for a detailed analysis of vegetation. A pre-treatment vegetation survey was conducted at this site in July, 1982, and the site was then split into 2 halves. The soil in the west half was not reclaimed. The soil in the east half was reclaimed according to the procedure given above. Following irrigation, both halves of the area were broadcast seeded in the fall of 1982 with a mix of native grasses including $7 \mathrm{~kg} / \mathrm{ha}$ western wheatgrass, $3 \mathrm{~kg} / \mathrm{ha}$ blue grama, $8 \mathrm{~kg} / \mathrm{ha}$ sideoats grama, $12 \mathrm{~kg} / \mathrm{ha}$ green needlegrass, and $18 \mathrm{~kg} / \mathrm{ha}$ needle and thread. A reference site with similar slope, aspect and soil about 1 ha in size was selected about $100 \mathrm{~m}$ further west where no visible damage had occurred as a result of the blowout. The vegetation growing on the reclaimed, unreclaimed, and reference sites was analyzed again in July 1984. 
Table 1. Percent basal cover on the salt water contaminated site and nearby reference area in 1982 and 1984.

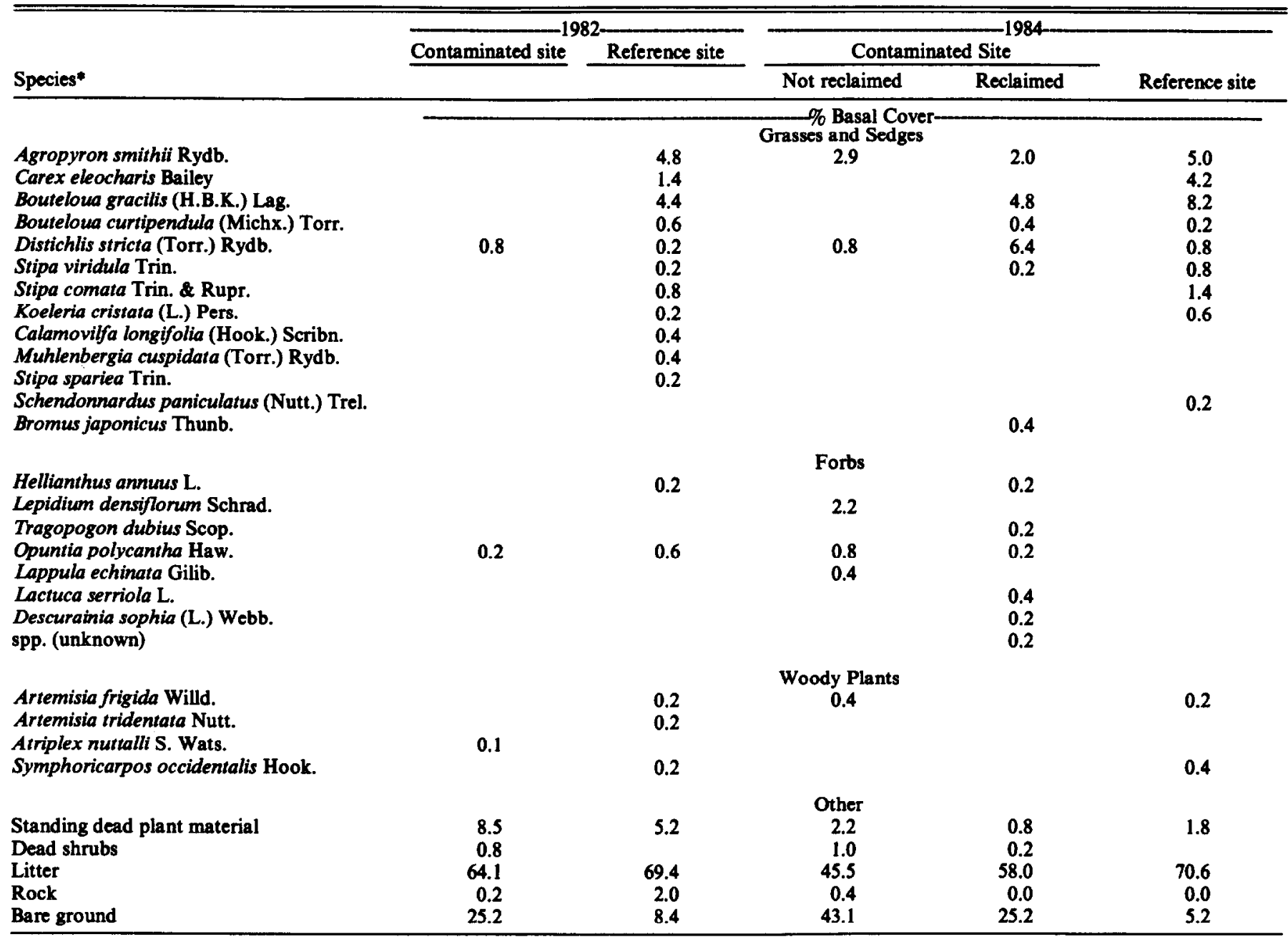

*Stevens, 1963 was the source used for species names and authority.

The vegetation analysis consisted of counts of plant density and estimates of basal cover of different plant species. Basal cover was estimated from basal hits using a vertical ten-point frame quadrat with points spaced $5 \mathrm{~cm}$ apart. Fifty randomly located frames $(\mathrm{n}=$ 500) were measured on the contaminated site in 1982 and 50 frames on each of the reclaimed and unreclaimed halves of this site in 1984. Twenty-five frames $(n=250)$ were measured on the reference area in 1982 and 1984. Plant density was estimated by counting the number of plants by species in an area of $0.09 \mathrm{~m}^{2}$. Plant density measurements were made at 25 randomly selected spots on the reference area in 1982 and 1984 and at 25 spots on the reclaimed and at 25 spots on the unreclaimed halves of the contaminated site in 1984. No live plants were measured in the density counts on the contaminated site in 1982.

Soil samples to a depth of $15 \mathrm{~cm}$ were taken from 39 sites located throughout the entire area contaminated by the salt water. Of these sites 27 were treated and 12 were untreated in the reclamation process. These 12 sites were not treated because they were set aside for further scientific study or were inaccessible or were not reclaimable. The soil was also sampled at 4 reference sites some distance away from where visible damage to the vegetation had occurred. The soils varied considerably throughout the contaminated area. The predominant soil in the contaminated area including that portion used for the vegetation analysis was a Cherry silty clay loam (fine-silty, mixed, frigid Typic Ustochrept) which is deep, well drained, moderately slowly permeable and formed in recent alluvium. Soil samples to a depth of $15 \mathrm{~cm}$ were obtained in July 1982 prior to soil treatment and in July 1984 following soil treatment and revegetation.

Three of the soil sampling sites were located within the contaminated area where the vegetation analysis occurred. Two of these sites were reclaimed and the third one was not reclaimed. The 2 sites which were reclaimed had average values for SAR and EC of $77 \pm 36$ and $20 \pm 17$ in 1982 in the surface $15 \mathrm{~cm}$. These values had decreased in 1984 to $12 \pm 12$ and $7 \pm 1$ respectively. The site which was not reclaimed had SAR and EC values of 38 and 13 in 1982 and values of 26 and 10 , respectively in 1984 .

Electrical conductivity of saturation extracts (EC) was measured using a conductivity bridge (Bower and Wilcox 1965). Chlorides were measured by titration with silver nitrate (Bower and Wilcox 1965). Soluble salts were determined on saturation extracts (Bower and Wilcox 1965) and soluble $\mathrm{Ca}, \mathrm{Mg}$, and $\mathrm{Na}$ concentrations were determined quantitatively using atomic absorption spectrophotometry. Sodium adsorption ratio (SAR) was calculated from the soluble $\mathrm{Ca}, \mathrm{Mg}$, and $\mathrm{Na}$ concentrations.

Data for percent basal cover and plant density were analyzed statistically using the $Z$ test (for unpaired observations and unequal variances p. 81, Steel and Torrie 1960). Comparisons were made between the contaminated site in 1982, the reference site in 1982 , the reference site in 1984, and the reclaimed and unreclaimed portions of the contaminated site in 1984 for each category of vegetation. Soil samples were analyzed statistically using analysis 
Table 2. Plant denalty at the salt water contaminated aite and nearby reference aree in 1982 and 1994.

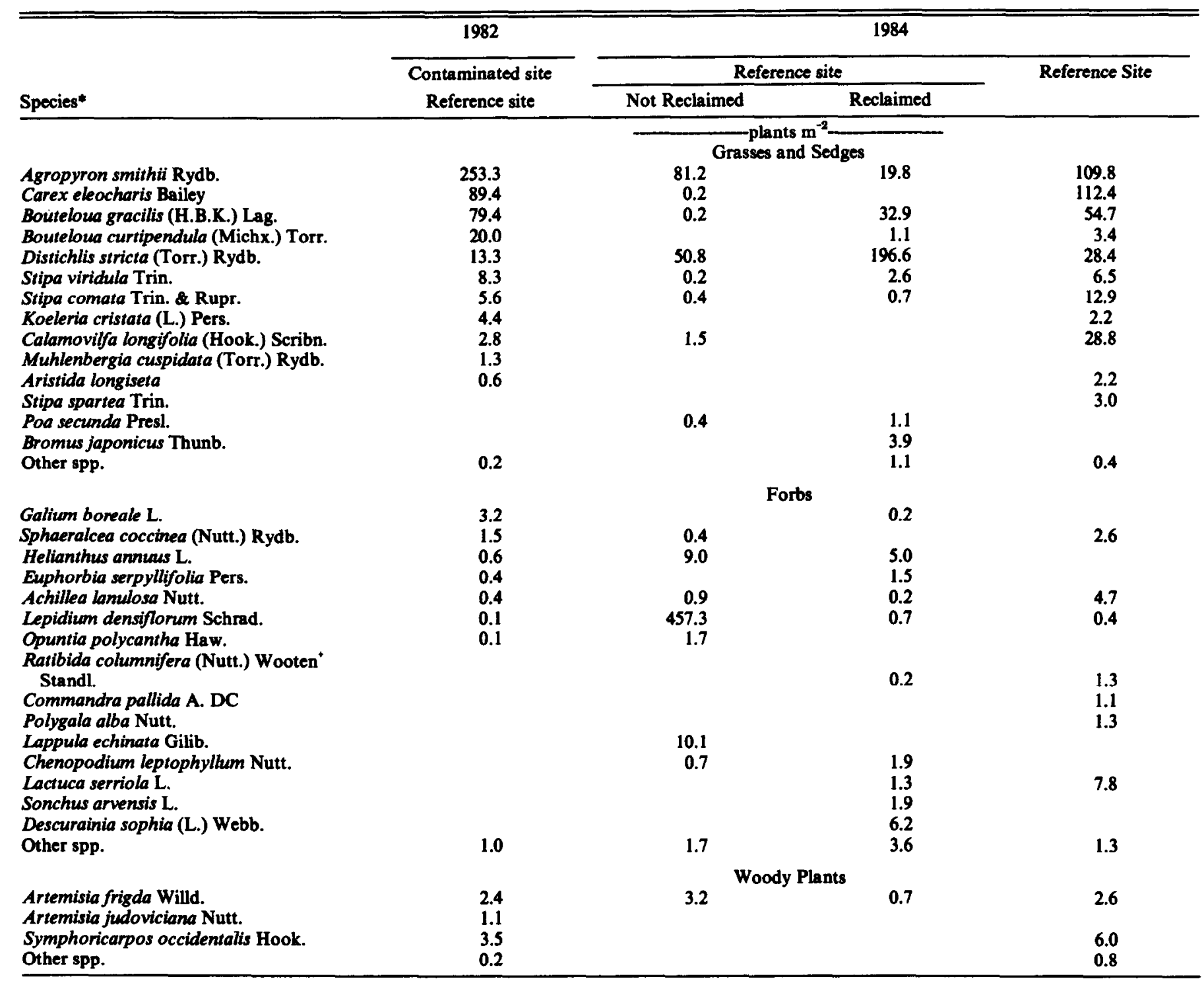

IStevens, 1963 was the source used for apecies names and authority.

of variance with the site (reclaimed, unreclaimed, and reference) and the time of analysis $(1982,1984)$ as the dependent variables. Interaction means for site*time of analysis were compared using Tukey's honestly significant difference (hsd).

\section{Results and Discussion}

The extent of the damage to vegetation from the blowout can be seen from 1982 basal cover data (Table 1). Only a few specimens of a few species were alive in July 1982 on the contaminated areas. Of the grasses only infrequent small patches of inland saltgrass were alive. This is in comparison to the 14 different grass and sedge species at the nearby reference site. Reference site species with the highest percent basal cover were western wheatgrass, needleleaf sedge (Carex eleocharis), blue grama, and needle and thead. A few prickly pear cactus (Opuntia polycantha) were severely damaged by the salt water, but did survive. Isolated specimens of Nuttall saltbush (Atriplex nuttallii) were also measured with the point frame quadrat in 1982. In contrast, 5 species of woody plants were sampled using the point frame quadrat or in plant density counts at the reference site (Table 2).

By 1984 the number of plant species had changed on the contam- inated site (Table 1). On the reclaimed half of the site 8 grass species were identified. The species with the highest percent basal cover and density were western wheatgrass, blue grama, and inland saltgrass. In the half of the contaminated site which was not reclaimed 8 grass species were identified, and of these only 2 , western wheatgrass and inland saltgrass, had appreciable percent cover or plant density measurements (Tables 1 and 2).

Thirteen forbs were identified on the reclaimed site in 1984. Species with highest plant densities were common sunflower (Helianthus annuus) and flixweed (Descurainia sophia) (Tables 1 and 2). On the unreclaimed half of the contaminated site, 7 species of forbs were identified, of which pepperweed (Lepidium denisflorum) was the dominant species in terms of plant density (Table 2). Other important contributors to plant density on the unreclaimed site were common sunflower and blue stickseed (Lappula echinata) (Table 2). The number of forb species was higher on the reclaimed and unreclaimed portions of the contaminated site in 1984 than in 1982. This was due to the appearance of invader species such as pepperweed which moved into the area following elimination of the original vegetation. Fringed sage (Artemisia frigida) was the only woody species noted in either cover or plant density measure- 
Table 3. Summary of \% basal cover and plant denaity at the sult water contaminated site and nearby reference area in 1982 and 1984.

\begin{tabular}{|c|c|c|c|c|c|}
\hline \multirow[b]{2}{*}{ Component } & \multicolumn{2}{|c|}{1982} & \multirow[b]{2}{*}{$\begin{array}{l}\text { Reference } \\
\text { site }\end{array}$} & \multirow{2}{*}{$\begin{array}{l}\text { Contaminated site } \\
\text { not reclaimed }\end{array}$} & \multirow{2}{*}{$\begin{array}{r}\text { Contaminated site } \\
\text { reclaimed }\end{array}$} \\
\hline & $\begin{array}{l}\text { Reference } \\
\text { site }\end{array}$ & $\begin{array}{c}\text { Contaminated } \\
\text { site }\end{array}$ & & & \\
\hline $\begin{array}{l}\text { Grasses and sedges } \\
\text { Forbs } \\
\text { Woody species } \\
\text { Dead plant material }\end{array}$ & $\begin{array}{c}13.6 \mathrm{~b}^{*} \\
0.8 \mathrm{~b} \\
0.6 \mathrm{a} \\
76.2 \mathrm{a}\end{array}$ & $\begin{array}{l}\text { Cover, \% Basal } \\
0.8 \mathrm{~d} \\
0.2 \mathrm{~b} \\
0.1 \mathrm{a} \\
73.4 \mathrm{a}\end{array}$ & $\begin{array}{r}21.2 \mathrm{a} \\
0.4 \mathrm{~b} \\
0.6 \mathrm{a} \\
72.4 \mathrm{a}\end{array}$ & $\begin{array}{r}3.6 \mathrm{c} \\
3.4 \mathrm{a} \\
0.4 \mathrm{a} \\
47.8 \mathrm{c}\end{array}$ & $\begin{array}{r}14.2 \mathrm{~b} \\
1.2 \mathrm{~b} \\
0.0 \mathrm{a} \\
59.0 \mathrm{~b}\end{array}$ \\
\hline Bare ground, rock & $8.8 \mathrm{c}$ & $25.2 \mathrm{~b}$ & $5.2 \mathrm{c}$ & $42.6 \mathrm{a}$ & $25.2 \mathrm{~b}$ \\
\hline $\begin{array}{l}\text { Grasses and sedges } \\
\text { Forbs } \\
\text { Woody species }\end{array}$ & $\begin{array}{l}479 \mathrm{a} \\
7 \mathrm{c} \\
7 \mathrm{ab}\end{array}$ & Density, plants $/ \mathrm{m}^{2}$ & $\begin{array}{r}365 \mathrm{~b} \\
13 \mathrm{c} \\
9 \mathrm{a}\end{array}$ & $\begin{array}{r}135 \mathrm{~d} \\
483 \mathrm{a} \\
3 \mathrm{~b}\end{array}$ & $\begin{array}{r}260 \mathrm{c} \\
29 \mathrm{~b} \\
1 \mathrm{~b}\end{array}$ \\
\hline
\end{tabular}

*Values in each row followed by the same letter are not significantly different at the 5\% probability level.

ments on the reclaimed or unreclaimed sites in 1984 (Tables 1 and 2).

Grasses and sedges contributed approximately $14 \%$ basal cover at the reference site in 1982 (Table 3). On the contaminated site only $0.8 \%$ of the basal hits were made on grass or sedge species. There was almost no reestablishment of sedge species on the contaminated site. By 1984 the percent grass and sedge cover on the reclaimed site was $14.2 \%$, about two-thirds of the 1984 value on the reference site. Identifiable progress, therefore, had been made in reestablishing a grass cover on the reclaimed area. Basal cover of grasses on the unreclaimed area was $3.6 \%$, which was significantly less than on the reclaimed area. Nevertheless, this was a significant increase in basal grass cover over that found at the site in 1982. These figures indicate that some reestablishment of desirable perennial species was also occurring on the unreclaimed site.

The percent basal cover of forbs was not significantly higher on the reclaimed site than on the reference area in 1984, but was significantly higher on the unreclaimed site where it made up almost 50\% of the live plant cover (Table 3). Pepperweed accounted for most of the high forb density on this site. Because of the small size of this species, however, forbs provided only $3.4 \%$ of the basal cover.

The largest percentage of basal hits occurred on litter and standing dead plant material on all sites. Despite contamination from the blowout, percent basal cover provided by the dead plant material was virtually the same on the reference and the contaminated sites in 1982 (Table 3). Because live vegetation was eliminated, the percent bare ground was $25.2 \%$ on the contaminated site compared to $8.8 \%$ on the reference site in 1982 . Costin (1964) cited research which showed that about $70 \%$ cover (basal area plus litter) was the minimum necessary to prevent significant erosion. $A$ bare ground percentage of 27 did not significantly increase soil loss in a study on land reclaimed following stripmining in the Northern Great Plains (Ries and Hofmann 1984). Therefore, at the time of this survey in 1982, erosional losses were not expected to cause significant damage to the area.

The vegetation analysis showed that there were not statistical differences between 1982 and 1984 in the percent bare ground and percent basal cover of dead plant material on the reference site. On the reclaimed site the percent basal cover of dead plant material was 59.0 in 1984 compared to 73.4 in 1982 on the contaminated area. However, this loss of litter was compensated for by increased cover by grasses. The percent bare ground remained at about $25 \%$. Although no progress was made in reducing the percent bare ground, it did not increase. Assuming the vegetation cover continues to improve, the percent bare ground should decrease in succeeding years.

The basal cover of dead plant material on the unreclaimed portion of the contaminated site was $47.8 \%$ in 1984 , a value lower than on the reclaimed portion. In addition, the percent basal cover of grasses and sedges was significantly less than on the reclaimed portion or on the reference site. On the unreclaimed site bare ground was $42.6 \%$. At this level erosion losses could become important. Although the basal cover of grasses on the unreclaimed site was only about $25 \%$ of that on the reclaimed site, some revegetation by grasses and forbs had occurred.

The degree of contamination in soil samples following the blowout was very variable. The degree of contamination generally decreased with distance from the well. Mean values for $\mathrm{Na}^{+}$and $\mathrm{Cl}^{-}$ and $\mathrm{EC}$ in 1982 were very high compared to the reference areas (Table 4). By 1984 the mean values for $\mathrm{Na}^{+}$and $\mathrm{Cl}^{-}$and $\mathrm{EC}$ on the untreated sites had decreased significantly because of leaching of the salts by natural precipitation. The mean values for these parameters on the treated sites also decreased, but these decreases were not significant because of the high variability between sites.

Sodium and $\mathrm{Cl}^{-}$were also found in the reference area. Sodium is typically found in the soil profiles of the area, but $\mathrm{Cl}^{-}$is not since $\mathrm{SO}_{4}{ }^{-2}$ is the dominant anion in these geologic formations. Therefore, chloride can be used as a marker of contamination from the blowout. Since $\mathrm{Cl}^{-}$was present in the profile of the reference areas, some salt water probably fell during the blowout without visibly affecting the vegetation.

Since $\mathrm{CaCl}_{2}$ was used in the reclamation process the concentration of $\mathrm{Ca}^{+2}$, especially near the surface, increased, though not

Table 4. Soil chemical data for all soil sampling sites before reclamation (initial) and after reclamation (Inal) to a depth of $15 \mathrm{~cm}$.

\begin{tabular}{|c|c|c|c|c|c|c|c|c|c|c|}
\hline \multirow[b]{2}{*}{ Treatment } & \multicolumn{2}{|c|}{ SAR } & \multicolumn{2}{|c|}{$\mathrm{CA}^{2+}$} & \multicolumn{2}{|c|}{$\mathrm{Na}^{2+}$} & \multicolumn{2}{|c|}{$\mathrm{Cl}^{-}$} & \multicolumn{2}{|c|}{$\mathrm{EC}$} \\
\hline & Initial & Final & Initial & Final & Initial & Final & Initial & Final & Initial & Final \\
\hline & \multicolumn{2}{|c|}{$(\mathrm{meq} / \mathrm{l})^{1 / 2}$} & & $-n$ & & & \multicolumn{4}{|c|}{$(\mathrm{mmho} / \mathrm{cm})$} \\
\hline Treated & 78 & 20 & 22 & 32 & 304 & 64 & 351 & 98 & 32 & 10 \\
\hline Untreated & 106 & 70 & 51 & 22 & 682 & 287 & 811 & 314 & 64 & 30 \\
\hline Reference & 9 & 6 & 5 & 2 & 16 & 7 & 20 & 1 & 3 & 1 \\
\hline hsd (.05) & \multicolumn{2}{|c|}{45} & \multicolumn{2}{|c|}{37} & \multicolumn{2}{|c|}{307} & \multicolumn{2}{|c|}{438} & \multicolumn{2}{|c|}{34} \\
\hline
\end{tabular}


significantly. The net result was a significant decrease in the SAR of the reclaimed profiles (Table 4). Some reduction in SAR on the untreated sites also occurred as a result of redistribution of the salts in the profile since 1982. The mean SAR of these reclaimed sites was still too high for good vegetation development. It is expected, however, with further leaching of the salts by natural precipitation events that the SAR values will continue to decrease.

\section{Summary and Conclusions}

Following the salt water blowout in 1982, only a few small patches of inland saltgrass, isolated forbs, and isolated nuttall saltbush plants survived on the contaminated, vegetation analysis site. By 1984 on the reclaimed half of the site, a relatively diverse plant community was reestablished. Dominant grass species included western wheatgrass, blue grama, and inland saltgrass. On the unreclaimed half of the site in 1984, western wheatgrass and inland saltgrass were the dominant grass species. In 1984 the percent basal cover of grasses on the reclaimed site was about two-thirds of the cover on the refernce site. In 1982, $25 \%$ of the basal hits using a point frame quadrat were on bare ground on the contaminated area. Other studies have shown that erosion is not significantly increased at this level. In 1984 the percent bare ground was unchanged on the reclaimed site, but the percent bare ground increased to $42.6 \%$ on the unreclaimed site, leaving it in a condition in which increased erosion could occur.

The addition of $\mathrm{CaCl}_{2}$ in irrigation water to the affected site was successful in reducing the SAR of the affected soils. Natural precipitation caused some leaching of salts from the surface $15 \mathrm{~cm}$ of the soil on the unreclaimed sites. The presence of $\mathrm{Cl}^{-}$in the profile of the reference area indicated that some salt water contamination had occurred, but did not visibly affect the established vegetation.
Calcium chloride was found to be effective in reclaiming land devastated by a salt water blowout. Its utility in this situation was enhanced because it is more soluble than gypsum and could be leached into the profile and is readily available where oil drilling occurs.

\section{Literature Cited}

Bernoteln, L. 1958. Salt tolerance of grasses and forage legumes. USDA Agr. Information Bull. 194. US Gov. Print. Off., Washington, D.C.

Bower, C.A., and L.V. Wilcox. 1965. Soluble salts. In: Black, C.A. (ed.). Methods of soil analysis. Agron. 9:933-951.

Costin, A.B. 1964. Grasses and grasslands in relation to soil conservation. p. 236-257. In: C. Bernard (ed.). Grasses and Grasslands. MacMillan and Co. Ltd. New York.

Doering, E.J., and W.O. Willi. 1975. Chemical reclamation for sodic strip-mine spoil. ARS-NC-20. USDA, Peoria, Ill.

Francis, B.A., and C.R. Curtis. 1979. Effect of simulated saline cooling tower drift on tree foliage. Phytopathology 69:349-353.

Miller, T.R., and S.R. Chapman. 1978. Germination responses of three forage grasses to different concentrations of six salts. J. Range Manage. 31:123-124.

Petolino, J.F., and I.A. Leone. 1980. Saline aerosol: Some effects on the physiology of Phaseoulus vulgaris. Phytopathology. 70:229-232.

Ries, R.E., and L. Hofmann. 1983. Effect of sodium and magnesium sulfate on forage seed germination. J. Range Manage. 36:658-662.

Ries, R.E., and L. Hofmann. 1984. Pasture and hayland: measures of reclamation success. Minerals and the Environment. 6:85-90.

Ryan, J., S. Miyamoto, and J.L. Stroehlein. 1975. Salt and specific ion effects on germination of four grasses. J. Range Manage. 28:61-64.

Steele, R.G.D., and J.H. Torrie. 1960. Principles and procedures of statistics. McGraw-Hill Book Co., Inc. New York.

Stevens, O.A. 1963. Handbook of North Dakota plants. North Dakota Institute for Regional Studies, Fargo, ND.

U.S. Salinity Labontory Staff. 1954. Diagnosis and improvement of saline and alkaline soils. USDA Handb. 60. 